\title{
COMMUNAL SPACE AND COLLABORATIVE WRITING: \\ VILLANCICOS IN LISBON'S CONVENT OF SANTA CLARA
}

ANNA-LISA HALLING

Brigham Young University halling@byu.edu

ABSTRACT: A 1671 collection of villancicos written by the Poor Clares in Lisbon and printed only with the name of the vicaress of the choir, Isabel do Nacimento, reflects the communal nature of the convent and the practice of collaborative writing. The intramuros space allowed the nuns to foment a written culture and thereby nurture a collective feminine authorial voice. In these villancicos, we clearly hear the voices of a community of religious women as they join together in praise, humility, obedience, and sacrifice.

PALABRAS CLAVE: Communal space, collaborative writing, Poor Clares, villancicos. 


\section{ESPACIO COMUNITARIO Y ESCRITURA COLABORATIVA: villancicos en el convento lisboeta de Santa Clara}

RESUMEN: Una colección de villancicos de 1671 escrita por las monjas clarisas de Lisboa e impresa con solamente el nombre de la vicaria del coro, Isabel do Nacimento, refleja la naturaleza comunitaria del convento y la práctica de la escritura colaborativa. El espacio intramuros permitió a las monjas fomentar una tradición de escribir y así promover una narración femenina colectiva. En estos villancicos, escuchamos claramente las voces de una comunidad de religiosas unidas en alabanzas, humildad, obediencia y sacrificio.

PALABRAS CLAVE: Espacio comunitario, escritura colaborativa, monjas clarisas, villancicos.

ESPAÇO COMUNITÁRIO E ESCRITURA COLABORATIVA: villancicos no convento lisboeta de Santa Clara

RESUMO: Uma coletânea de vilancicos de 1671 escrita pelas freiras clarissas de Lisboa e impressa com somente o nome da vigária do coro, Isabel do Nacimento, reflete a natureza comunitária do convento e a prática de escrever de forma colaborativa. O espaço intramuros permitiu às freiras fomentar uma tradição de escrever e assim promover uma narração feminina coletiva. Em estes vilancicos, escutamos claramente as vozes duma comunidade de religiosas unidas em louvor, humildade, obediência e sacrifício.

PALAVRAS-CHAVE: Espaço comunitário, escritura colaborativa, freiras clarissas, vilancicos.

Crom Christine de Pizan to Virginia Woolf and beyond, women writers throughout the centuries have philosophized about the definitions of a women's space: the space in which women act alone and autonomously, space that enables women to create, communicate, and collaborate in ways not available to them in the public sphere. Few spaces function principally as "women's space" better than the cloistered convent. The walls of the convent were meant both to protect and control women, but this enclosure produced unexpected effects. While male ecclesiastical authorities theoretically could influence the women living intramuros (through practices such as confession), the women occupying convents have used this space to assert their individual and collective beliefs, struggles, and joys. The cloister has simultaneously limited and liberated nuns by providing them rare opportunities for self-expression and exploration. It is a collaborative and communal space. A 1671 collection of villancicos ${ }^{1}$ performed in the Real Convento de Lisboa ${ }^{2}$ reflects the communal space of the convent through the anonymity of its author(s) and composer(s) as well as through its references to the cooperative nature of the practices and beliefs of cloistered mulieres religiosae dedicated to the cultivation of spiritual life.

Spatial theorists such as Henri Lefevbre, Edward Soja, and Michel de Certeau argue that a space is defined not in terms of its physical construction, but rather through the combination of a location (and its infrastructure) and the practices that occur within the geographic limits of that location. Other spatial theorists emphasize the intersections of space and culture. Daphne Spain, in particular, reminds us that spaces are always strongly influenced by gendered practices. She insists that "although women's status is a result of a variety of cultural, religious, and socioeconomic factors, the physical separation of women and men also contributes to and perpetuates gender stratification" (Spain,1993: 137). Spain also notes that "both geographic distance and architectural design establish boundaries between the knowledge available to women and that available to men" (1992: 5) in order to "produce and reproduce power and privilege" (1992: 3). Gendered spaces such as seventeenthcentury convents serve to "reinforce and reproduce prevailing status

${ }^{1}$ This collection appears in a fourteen-page pamphlet published by the Impressão de Antonio Craesbeeck de Mello, one of the principal publishing houses in Lisbon during the early modern period. It does not include page numbers. It contains five villancicos (four written in Spanish and one in Portuguese) and each is numbered and divided into sections. For example, Villancico I includes a romance, an estribillo, coplas, and a repetition of the estribillo. Villancico IV contains an estribillo and a jácara.

${ }^{2}$ This title most likely does not refer to a specific convent but rather to the social status of the Convent of Santa Clara in Lisbon. The remnants of this convent are located on the corner of Rua do Mirante and Becco do Mirante, near the Santa Apolónia Train Station in Lisbon.

UNED. REI, 8 (2020), pp. 53-77

ISSN 2340-9029 
distinctions that are taken for granted" (Spain,1993: 137). However, this spatial division also allows for the development of new knowledge and a very different kind of authority, both of which occur largely in spite of the outside imposition of male influence. Although a certain stratification does occur within the convent, whether through the distribution of positions of leadership or the presence of servants or slaves, there is a communal and communitarian nature within convent walls as evidenced by the physical construction of its space in combination with the practices that occur therein.

These spatial theories directly inform any exploration of cultural artifacts produced by women in the communal space of the convent. One such artifact is a collection of villancicos ${ }^{3}$ sung by nuns in the royal convent of Lisbon on St. Clare's day (August 11) ${ }^{4}$ in the mid 1600s while Sor Isabel do Nacimento ${ }^{5}$ served as the vicaress of the choir. This text consists of five villancicos celebrating St. Clare and written in both Spanish and Portuguese. These writings reveal a performance tradition within Portuguese convents during the early modern period and offer unusual insight into the shared convent space within which nuns created these performative poems and brought them to life through song. The women's space of the cloister, with its physical characteristics and its religious and communal practices, provided women religious with a unique set of conditions that allowed them to express themselves through the arts. This compendium of villancicos reflects both the communal nature of the convent space and the collective anonymity of its residents who shared a common goal.

\footnotetext{
${ }^{3}$ The title page of this collection uses the Spanish term villancicos. In Portuguese, this same literary genre is referred to using the interchangeable terms vilancicos, vilhancicos, vilancetes, and vilhancetes. For the purposes of this article, I will use villancico.

${ }^{4}$ This is consistent with the fact that "[1]o habitual era interpretar villancicos en la festividad del patrón titular de una iglesia" (Torrente, 2016: 488).

${ }^{5}$ Although the title page uses the Spanish term "Sor", Isabel's religious title in Portuguese would have been Soror. The modern spelling of her adopted surname in modern Portu-
} guese is "Nascimento".
Like some other villancicos published in the seventeenth century, this particular set is not attributed to any one author. As Álvaro Torrente notes in his extensive study of the seventeenth-century Iberian villancico, "Los textos de los villancicos son en su mayoría anónimos y, en aquellos casos en que conocemos la autoría son pocos los poetas de renombre, a pesar de que la mayoría de los grandes poetas contribuyeron al género en algún momento" (2016: 455). In her article discussing the villancico genre, Esther Borrego Gutiérrez explains that in most cases, villancicos were composed through a joint effort by both the master of the choir (who composed the music) and the poet (who wrote the lyrics), with the second contributor typically remaining anonymous. ${ }^{6}$ She laments, "es curioso que se pueda obtener una cantidad de información nada desdeñable sobre impresores, imprentas, maestros de capilla, Iglesias y sedes catedralicias, detalles de la celebración etc., y apenas nada sobre los autores de las letras, o para hablar en términos de época, sobre los poetas" (2012: 104). In spite of arguments to the contrary, ${ }^{7}$ this anonymity is not due to the supposed lesser nature of the genre nor its authors, since eminent authors such as Lope de Vega, Sor Juana Inés de la Cruz, Luis de Góngora, Agustín Moreto, and Pedro Calderón de la Barca also wrote villancicos.

While other factors ${ }^{8}$ may have been at play in the anonymity common among the secular villancico poets, I argue that, as is the case

${ }^{6}$ As Borrego Gutiérrez explains, "la autoría de estas piezas era doble en la mayoría de los casos: por una parte, el maestro de capilla, que era el encargado de componer la música ...y por otra, el poeta, que componía los textos al menos un mes antes de su ejecución para poder pasar por el censor correspondiente" (2012: 102).

${ }^{7}$ Borrego Gutiérrez cites Tardes entretenidas en seis novelas and História del Buscón llamado don Pablos (both of which speak pejoratively about villancicos) to show that the "carácter acotado, cerrado, pecuniario e incluso intrascendente de este tipo de literatura .. propiciaría la anonimia" (2012: 127). They were, however, widely popular during the early modern period and Andrea Bombi asserts that for modern researchers, "la relevancia del género no puede ponerse en discusión" (2019:4).

${ }^{8}$ Borrego Gutiérrez notes the "reutilización de textos de villancicos de la Capilla Real" (2012: 101). This passing around of texts for repeated use may have contributed to their anonymous nature. She also suggests that not including the author's name was simply customary practice. Additionally, their similarity to other short theatrical genres (such as 
in some other convent writings, ${ }^{9}$ the creation of these short dramatic pieces was a collaborative effort, reflecting the nature of convent life itself. ${ }^{10}$ Speaking of the process of publication, Karen Emmerich notes that the recognition of the work of "publishers, editors, copyeditors, and designers" and their contributions promote "an understanding of literary creation as a social rather than a solitary endeavor" (2017: 17-18). Sor Isabel's collection likewise passed through and was molded by the hands of many people on its way to the printing press. However, I argue that this text was a cooperative endeavor from its very inception. Although, as Heather Hirschfield points out, "collaboration and collaborative authorship are the terms now used to designate a range of interactions, from the efforts of two writers working closely together to the activities of printers, patrons, and readers in shaping the meaning and significance of a text" (2001: 610), I use the term "collaborative" to refer to a shared process by which several authors create a single text. Though the text itself does not explicitly indicate a communal approach to writing - only Sor Isabel's name and title appear on the title page ${ }^{11}$ - and while we have

entremeses and jácaras) may explain the lack of established authorship, since these other genres also have difficulties with authorial attribution. Their anonymity may also be tied to their origins in cancioneros (Paul Laird, 1977, notes they first appeared in the fifteenth century), which often contained anonymous poems.

${ }^{9}$ During the early modern period, the nuns residing in a Carmelite convent in Valladolid, Spain, wrote a collection of unsigned poems found in Libro de romances y coplas del Carmelo de Valladolid, c. 1590-1609. The editors of the 1982 edition of the collection call it "una obra comunitaria conventual" (García de la Concha/ Álvarez Pellitero, 1982: XXI), indicating that the text is the product of work performed by many sisters in the conven and that the poems themselves were left unsigned in the original manuscript. The biological and spiritual sisters Sor Cecilia del Nacimiento and Sor María de San Alberto also lived and wrote poetry and plays in this convent during the period of collective poetic production, a testament to the literary spirit present intramuros during their tenure.

${ }^{10}$ The Constituiçoens geraes, written for Franciscan convents, underscores the importance of the communitarian aspect of convent life: "Nam ha cousa mais encom[en]dada na Regra, nem mais guardada em os Conventos bem disciplinados, que a guarda da vida cõmua entre as Religiosas, como por sua profissão estão obrigadas. Por tãto as exhortamos, que pelo amor de Deos se onformem com ella, assistindo a todos os actos de comunidade, quanto lhes for possivel" (1693: 89).

${ }^{11}$ The title page reads, Villancicos que cantaram as religiosas de S. Clara, em o seu dia no Real Convento de Lisboa: Sendo Vigaira do Coro a Madre Sór Isabel do Nacimento. no extant historical documents to attest to this theory, we must recognize the distinct possibility of collaborative creativity in the convent, where most women worked and worshipped in anonymity. As Nieves Baranda states, "Debemos recordar que el convento actuaba como unidad de convivencia y dedicación religiosa cuyo destino era superior a cada uno de los miembros que lo conformaban" (2011:570). The collective community was more important than the individuals that comprised it. Sor Isabel's position as vicaress of the choir, along with the cited performance of the villancicos, point to the communal environment in which these women lived, worked, and worshipped.

While there is "evidence of a richness and diversity of collective writing practices in Early Modern non-dramatic literature" (York, 2002: 67) - including letters, translations, and the use of scribes - most scholarly studies on early modern anonymous and communal writing deal with drama ${ }^{12}$ (principally in France and England). Villancicos are, likewise, a dramatic form. Although many texts from this time period are products of a collaboration in which "co-creators are not working consciously together" (Limbert/ O’Neill, 1993: 492), "composite authorship"13 implies the conscious co-creation of a text. Some studies on this type of authorship focus on texts produced by husbands and wives ${ }^{14}$ or priests and nuns, ${ }^{15}$ but

Borrego Gutiérrez confirms that the villancico genre "se caracteriza en general por su anonimia, pues aunque en alguna occasion se ha querido simplificar y atribuir las letras a los mismos maestros de capilla" (2012: 99).

${ }^{12}$ Theater is by nature a collaborative effort. As Lukas Erne states in the introduction to his study on Shakespeare, "Prior to performance, the play text was subject to a process of theatrical adaptation for which the company as a whole rather than the playwright alone must have been responsible" (2008: 2).

${ }^{13}$ Limbert and O'Neill coin this term in their article on the early modern poet Katherine Philips (1983).

${ }^{14}$ See, for example, Erica Longfellow's "Lady Anne Southwell's Indictment of Adam" in which she uses documentary evidence to study a collaboration between Southwell and her husband that served to establish the early modern author as "an ideal gentlewoman of letters" (2016: 112). Longfellow argues that "a husband's participation in a woman's manuscript was as often a shared promotion of the family as it was an act of suppression" (2016: 112).

${ }^{15}$ See, for example, Elizabeth Teresa Howe's book, Autobiographical Writing by Early 
there is a dearth of studies on communal writing among nuns themselves. One notable exception is Nieves Baranda's excellent article on convent writing, in which she explores what she calls "escritura en colaboración" and affirms that many convent texts "se escriben por obediencia ... y se conciben para uso de la comunidad, nunca como una pieza de creación individual" (2011: 573). I argue that Sor Isabel's collection of villancicos provides insight into a possible composite authorship situated in the communal experience and practices of the convent.

During the early modern period, men were the principal creators of cultural content. While the Renaissance "was a time of widespread public collaborative activity", "the conventions of public life made it very difficult for women to participate in that burgeoning collaborative creativity" (York, 2002: 65). In their quest to include women writers in the literary canon - particularly convent writers-scholars have tended to focus on single-authored texts, even though "son muy pocas las obras impressas donde la autoría se atribuye en portada a una monja" (Baranda, 2011: 572). This effort is meant to combat the excuses (such as those Joanna Russ outlines in her How to Suppress Women Writers ${ }^{16}$ ) that critics have traditionally employed to argue against the quality and acceptability of female-authored texts. ${ }^{17}$ Although this tactic certainly has called much-needed attention to once-forgotten voices, such as that of Soror Violante do Céu, Heather Hirschfeld argues that "it is incumbent

Modern Women, in which she explores the collaborative nature of both convent confessions and the editing of texts produced intramuros. She sees as "collaborative rather than adversarial" the relationship between Santa Teresa and the men editing her work because they were "less interested in suppressing what she wrote and more committed to assuring that it was theologically correct" (2015: 76).

${ }^{16}$ Russ begins the eighth chapter of her book with the following list: "She didn't write it. She wrote it, but she shouldn't have. She wrote it, but look what she wrote about. She wrote it, but 'she' isn't really an artist and 'it' isn't really serious, of the right genre-i.e., really art. She wrote it, but she wrote only one of it. She wrote it, but it's only interesting/ included in the canon for one, limited reason. She wrote it, but there are very few of her" (1983: 76).

${ }^{17}$ In the case of the convent playwright Sor Marcela de San Félix, for example, scholars often cite her parentage (she was the daughter of the great Lope de Vega), rather than simply noting her talent, in an effort to legitimize her literary production. on scholars who wish to reclaim lost or forgotten female voices to move beyond the dominant Romantic definition of the individual author and to recognize, in the diversified processes of textual production, alternative formulations or experiences of authorship" (2001: 615). Often, literary critics tend to overlook or discount collaboratively authored texts. In many cases, the impulse of feminist scholars is to seek to attribute authorship as a way of recovering female voices, and while this is certainly a worthy endeavor, Sor Isabel's collection of villancicos does not lend itself to this kind of identification. Indeed, attempting to assign individual authorship to this text would disregard the documented (and possible) types of collaborative production - whether staging plays or producing products to sell- that is essential to communal life. Whether individually or cooperatively written, I contend that these dramatic poems must have played an important role in the convent. Published with only the name of the community and that of the vicaress of the choir, it seems clear that they served to strengthen the sense of community in the convent while lauding their patron saint.

The authors and composers of villancicos, dramatic songs accompanied by instruments and replete with references to costuming and dance, wrote these texts specifically for performance. Paul Laird notes that villancicos were "a literary form to be sung" and "one of the most pervasive musical genres in the Western world" (1997: 3-4), particularly in Spain and Portugal. ${ }^{18}$ Although the term villancicos evokes Christmas carols for many modern readers familiar with Hispanic culture, during the early modern period this literary genre was performed for many different festivities throughout the year. While, as Maricarmen Gómez observes, a "remarkable percentage" of villancicos were in fact written for

18 Torrente insists that the high number of "concordancias" between the collection of "manuscritos musicales" belonging to the king of Portugal and the Spanish pliegos indicates that the villancicos performed in Lisbon's Capela Real "eran mayoritariamente de procedencia española" (2016: 461). However, the collection of villancicos discussed here were written in both Spanish and Portuguese, thus suggesting that they are not simply a translation of Spanish-language texts, but rather a collection of dramatic poetry composed in Portugal.

UNED. REI, 8 (2020), pp. 53-77

ISSN 2340-9029 
and performed during Christmas (2006: 64), ${ }^{19}$ many more dealt with a wide variety of topics. Laird explains that they even served as "substitutes for Latin responsories during matins on high feast days" and were "performed during Corpus Christi processions" (1997: 20). For example, the two-hundred and fifty villancicos written by Soror Violante do Céu arguably the largest collection of villancicos written by a nun (published in her Parnaso Lusitano in 1646) - were intended for performance on a wide variety of religious occasions, including celebrations for certain saints (particularly John the Baptist), holy events (such as the Ascension), and the profession of new nuns. ${ }^{20}$ Likewise, the villancicos directed by Sor Isabel do Nacimento, while deeply religious, have little to do with the Nativity. Rather, they provide us with insight into the communal nature of convent space.

The writing, composition, and performance of convent music (like other forms of art produced intramuros) was a highly personalized affair. In her article on the Catholic liturgy, Anne Bagnell Yardley explains that music in the convent "helped the nuns visualize their vocation in easily understandable concepts" (1990: 315) and that the parameters of liturgical performance depended "on the location and order of a particular establishment" (1990: 305). ${ }^{21}$ Besides responding to the spaces where they were created, villancicos were also highly didactic. Andrea Bombi notes that while "el villancico es un instrumento de persuasion y adoctrinamiento" (2019: 17), we should also consider this genre as "un potente instrumento de creación identitaria" (2019: 18). In their article on Portuguese convent life, Lígia Bellini and Moreno Laborda Pacheco affirm that "Os textos escritos por religiosas parecem dirigir-se prioritariamente às suas próprias companheiras nos conventos. Cumprir uma função pedagógica e de

${ }^{19}$ Gómez also argues that the very first villancico performance in Spain (in the cathedral of Toledo) was "linked ... to the Christmas Lauds" (2006: 68).

${ }^{20}$ For more on Soror Violante and her villancicos, see my article "Space, Performance, and Subversion in Sóror Violante do Céu's Villancicos" (Halling, 2017).

${ }^{21}$ Torrente (2016) notes the participation of Sor Juana Inés de la Cruz in the creation of this genre but insists she was an anomaly. We do, however, have evidence of other women writing villancicos, particularly Soror Violante do Céu, who penned 252 in her Parnaso Lusitano de Divinos, e Humanos Versos (1733). exemplaridade é um dos objetivos predominantes da literatura conventual feminina no Portugal da época" (2009:151). They also point out that convent authors intended to "ressaltar, para instituições, grupos e indivíduos fora dos conventos, o valor da comunidade religiosa, através do enaltecimento das monjas que dela faziam parte" (2009: 152). Although the nuns may have performed these villancicos for a more general public, their content indicates that their purpose was to celebrate and strengthen the convent community through performance while communicating the value of that community to those living extramuros.

The nuns who sang the villancicos in this collection were Franciscan $^{22}$ and resided in the Mosteiro de Santa Clara. The five volumes of João Bautista de Castro's Mappa de Portugal reveals that this "Mosteiro amplissimo" contained "duas varandas, e algumas Capellas" in addition to "dormitórios, e casas particulares" in which over 600 women lived (1758: 447). Among the inhabitants of this convent were nuns, students ("Religiosas educandas"), lay nuns ("recolhidas"), servants ("criadas"), and slaves ("escravas"). Almost all of the convent, including "O seu famoso Templo, que era hum monte de ouro, e na grandeza excedia a todos os mais Mosteiros da Corte" (Castro 1758: 448), was destroyed in the 1755 Lisbon earthquake, tragically causing the death of almost all its inhabitants. ${ }^{23}$ At the time of the villancico performance, however, the convent must have been a busy, bustling place with so many women from such disparate social spheres living and working together. The presence of servants and slaves also indicates the high socio-economic level of the convent's nuns, suggesting generally elevated educational opportunities. The author(s) and composer(s) of the villancicos, then, most likely came from the upper echelons of society and worked collaboratively to craft

\footnotetext{
${ }^{22}$ Castro (1758) designates this community as Franciscan in his Mappa de Portugal. Because St. Clare was a follower of St. Francis and the founder of her order, the Poor Clares are a branch of the Franciscan order.

${ }^{23}$ Castro explains that the convent "servio de sepultura com suas ruinas a quasi todas as Religiosas, que foraõ cincoenta e seis, além de oito educandas, huma noviça, quatorze recolhidas, quarenta e tres criadas, e nove escravas" (1758: 448).
}

UNED. REI, 8 (2020), pp. 53-77

ISSN 2340-9029 
these poetic performance pieces just as they worked collaboratively on other tasks within the convent.

Early modern convent manuals provide insight into this environment and the shared labor of participating in the choir. ${ }^{24}$ In particular, the Constituiçoens geraes pera todas as freiras, e religiosas sogeitas à obediencia da Ordem de N. P. S. Francisco, nesta Familia Cismontana affords insight into the inner workings of convent life and points to practices carried out in contemporaneous Franciscan convents and orders such as Sor Isabel's. The detailed instructions in this text reveals an innate theatricality imbedded in convent life. The nuns performed (or avoided) certain actions (“As Freiras Descalças da primeira Regra naõ comeràm carne , senão em tempo de necessidade; \& jejuaràm todos os dias" [Constituiçoens geraes, 1693:151]), wore particular clothing (“As Freiras Descalças da primeira Regra da Sãta Clara usarám das roupas declaradas na sua Regra" [ibidem: 153]), and recited rote prayers ("o Te Deum laudamus, \& Laudes; Prima, \& Completas se dirám rezadas" [ibidem:76]). Through uniformity, the nuns' movements, clothing, and singing were intended to establish a sense of anonymity within the group, a denial of the self for a greater purpose.

In addition to providing instruction for the members of the choir, these manuals also delineate how the vicaress of the choir should carry out her duties. The nun in this position must be familiar enough with the necessary ceremonies to teach and correct her sisters ("Seja muyto cuidadosa em estudar as ceremonias . . . pera que as possa ensinar, \& fazer praticar às Religiosas" [ibidem: 120]). She must also know when and how to perform the approved music "pera que haja uniformidade, \& consonancia; tendo grande cuidado em que as Religiosas ajudem ao

${ }^{24}$ Although each religious order had its own rule, a few Iberian conduct manuals written for specific convents - such as the one mentioned here- currently exist. Examples of this type of text are Suma y breve compilación de cómo han de bivir y conversar las religiosas de Sant Bernardo que biven en los monasterios de la cibdad de Ávila (c.1507) by Hernando de Talavera (see Cécile Codet's 2012 edition), Ceremonial del convento (Sanz 1681), and Excelencias de la castidad (Padilla, 1642). These manuals contain specific guidelines for the practices and procedures of convent life, including guidance on such topics as how to read the oratory aloud and the number of candles that the nuns should light before the celebration of Corpus Christi.
Coro em o cantado, \& rezado" (ibidem:119-20). Most importantly, she must work closely with the other nuns and must correct them (when necessary) "cõ caridade" and "com muita modestia, \& silencio" (ibidem: 120). What is more, the choir space in particular "não era lugar de manifestações individuais de louvor" (Bellini/ Pacheco, 2009: 154), but rather a place to worship communally. Sor Isabel's actions would have ensured the quality of the production of these villancicos, as she served as a facilitator tasked with organizing a communal effort rather than as a star performer.

The life of the founder of the Franciscan order of St. Clare also underscores the communal nature of the convent. Joan Mueller explains that although St. Francis instructed the nun to accept the title of abbess, she accepted only because she had promised her mentor obedience. In spite of her new appointment, St. Clare continued to perform menial tasks within the convent, such as washing the hands of the other nuns before meals, serving food, and tending to sick sisters. She even washed the feet of other nuns, according to the Franciscan rule. Mueller insists that Clare's actions were "more than an example of a pious person attempting to evade prominence" (2006: 17). Rather, they were proof of her devotion to a communal convent life in which no one adherent elevates herself over another.

This devotion permeates the rule of St. Clare, as well. ${ }^{25}$ This set of guidelines reveals the importance of community and communal endeavors. For example, St. Clare's rule states that, unlike their Franciscan brothers, new members of the community were admitted by the abbess only after seeking "the consent of all the sisters" (Morris, 2006: 103), the majority of whom had to approve the decision. The communal nature of

${ }^{25}$ While St. Francis originally wrote a forma vitae, it was not considered an official rule but rather simple guidelines specifically for St. Clare's convent and a few others. The nuns of Clare's convent originally followed the Rule of St. Benedict, which was later replaced by a modified rule written by Pope Innocent IV. Eventually, Clare wrote her own rule containing "the practice of intense poverty that Clare considered the heart of her religious commitment" (Morris, 2006: 100). A papal bull gave this rule final approval two days before Clare's death.

UNED. REI, 8 (2020), pp. 53-77

ISSN 2340-9029 
the Poor Clares is underscored by the main principle of the rule-that of absolute poverty. Unlike other orders, St. Clare's followers were "not to receive or hold onto any possessions or property" (ibidem: 110). They were allowed to collectively own property adjacent to their monastery, but even so the land was "not to be cultivated except as a garden for the needs of the sisters" (ibidem). While other orders and convents collected rents and managed estates, the Poor Clares had to rely on manual labor and alms for their sustenance. In other words, their limited holdings were shared possessions used not to enrich, but rather to sustain the community as a whole.

The Poor Clares, of course, were not the only religious community to experience this sort of unity and effacement of self in favor of the group. Indeed, all women religious took vows that underscored the communal nature of the convent. Upon professing, nuns left their secular name and identity behind to adopt a new one, becoming "dead to the world" in a figurative sense. Their familiar, romantic, and collegial associations severed and replaced, at least in theory, with strong connections to their God, their church, and their religious sisters. As Elizabeth Lehfeldt expounds, "male and female religious renounced their ties to the world of family, community, and temporal attachments and proclaimed their acceptance of a new life no longer bound by these distractions" (2005: 3). Their vows of chastity, poverty, and obedience replaced worldly cares and interests. In their writing, a rhetoric of humility allowed no room for self-aggrandizement. This separation from the world was, obviously, facilitated by strict rules of enclosure. Nuns gave themselves up to become something and someone else.

This sense of community is reflected time and again in this collection of villancicos. The nuns' common devotion to Saint Clare, for example, appears repeatedly in the texts. ${ }^{26}$ In Villancico I, the poetic voice refers to her as "nuestra Madre" and expresses the desire to "pintar sus prodigios".

${ }^{26}$ It comes as no surprise that these nuns would utilize villancicos as a way to celebrate and praise their patron saint. In fact, Torrente explicates that the Franciscan order began appropriating "el canto en vernáculo" in the Middle Ages and utilized it "de manera consciente ... como herramienta doctrinal" (2016: 442).
The dramatic poem identifies Clare and her beauty as the objects of affection, love, and devotion since by identifying themselves as her daughters, the nuns are repaid by their marriage to Christ and given a clear path to Heaven ("el que guarda su Regla, / Se encamina para el Cielo"). Although Jesus clearly occupies a central role in the lives of these women religious, the villancico admonishes them to love St. Clare "con extremos" and "todo el alma". The villancicos depict St. Clare not only as the nuns' patron saint, but also as an indispensable female intercessor with Christ. As Donna Spivey Ellington notes, this role traditionally falls to the virgin Mary: "[a] s Queen of Heaven after her Assumption, Mary was always portrayed as continuing the same close relationship with Jesus that she had enjoyed on earth, sitting at his right hand and ruling over the kingdom of Mercy as he administered the kingdom of Justice" (2001: 107). In this text, St. Clare's role may not appear identical to that of Mary, but she holds a privileged position nonetheless. Here she receives the titles "Madre", "querida Esposa", "Rosa", "Alva", and "Estrella", epithets often reserved for the mother of God. The festivities and devotions clearly center on her, not Christ or the Virgin Mary, and this serves as a reminder of the virtues of the founder of their order and the values of their community.

The villancicos also allude to shared experiences in the convent, particularly the vows taken by the nuns within the order. The followers of St. Clare were under the auspices of the Franciscan order and lived by the same principles of poverty, obedience, and chastity as did members of other religious orders. Villancico II deftly weaves these principles into the first section praising St. Clare for her efforts in founding their religious rule, or "Regra", and refers to her four times as "Aquella"; she who paradoxically insisted on poverty in order to ensure eternal riches ("Para serem muito ricas, / As faz prometer pobreza"), she who saves through obedience ("nos manda para a Gloria, / Sob pena de Obediencia"), she who guides the nuns to eternal life through chastity ("se eterna a [Castidade] tivermos, / Teremos a Gloria eterna"). This same text also references the order's vow of poverty by portraying St. Clare as one who went about "Descalça" and who "soube ser, / sem os adornos, fermosa 
/ Pois vestida de burel, / A todo o mundo namora". This vow, central to the order of the Poor Clares, helped equalize the sisters in the convent, thereby fostering a sense of community.

Another equalizing element that fostered a sense of community intramuros was the religious habit each sister adopted upon taking her vows. ${ }^{27}$ Like Franciscans, the Poor Clares dressed in robes made of "simple brown cloth and using a cord in place of a belt" (Bennett et al., 2016: n.p.). This habit related directly to the order itself, as it was most likely made of a type of woolen sackcloth called sayal, "a cheap undyed and coarse material that reflected the Franciscan dedication to poverty" (ibidem). As Clare herself stated, "For love of the most holy and beloved child who was wrapped in poor swaddling clothes and laid in a manger and of his Most Holy Mother, I admonish, beg, and exhort my sisters always to wear poor garments" (qtd. in Mueller, 2006: 115). The third villancico in Sor Isabel's collection references the Franciscan habit when it refers to St. Clare as "El Alva Hermosa" and the "Aurora tan clara" (a common allusion to the saint in this compendium) that the poetic voice sees appearing "En nubes pardas" and outshining the sun itself in spite of her humble dress. The brown of the clouds alludes to the color of the cloth used for the habits of the Poor Clares, a visual representation of their vow of extreme poverty. This villancico goes on to explain that "Las mismas nubes / Con el Sol, y la Aurora / se visten luzes" - just as the moon does not produce its own light but instead reflects that of the sun, St. Clare's resplendence shines on the sisters of her order as she shares her glory with them. Villancico IV also mentions the coarse woolen cloth used to make the nuns habits: "de un burel muy grossero / eran sus mejores galas". While these verses clearly praise St. Clare, they also allude to the habit worn by all the nuns of her order as a symbol of their vows of "poverty, chastity, obedience and enclosure" (Bennett, 2016: n.p.). Villancico II similarly portrays St. Clare as "Aquella que sobe ser, / Sem os adornos, fermosa, / Pois vestida de burel, / A todo o mundo namora" and also portrays the saint as barefoot. In addition to its simple habit, the order is discalced and the nuns would wear "sandals to reflect their commitment to poverty and the rejection of material comfort"

${ }^{27}$ This practice and several others described in this paper still occur today. (ibidem). Villancico IV points to this practice when it asserts that St. Clare herself, the "Niña gala de la tierra ... Anduvo siempre descalça". Dress not only linked these women religious to their founder, but also to each other as integral members of a community devoted to a common purpose.

In addition to wearing a humble habit, this Franciscan order adhered generally to a strict code of poverty that severely limited and controlled both the private possessions of the nuns and the general holdings of the convent, as mentioned earlier. Unfortunately, "From the time of their formation, the Poor Clares were under pressure to give up their dedication to absolute poverty because it thwarted prospective patrons" (ibidem). This led to fluctuations in the strictness of the order's adherence to this rule. ${ }^{28}$ Nevertheless, the vow of extreme poverty taken by the nuns still played a central role in their identity and in the formation of community within convent walls. This theme appears repeatedly Sor Isabel's villancicos. Villancico II states that St. Clare makes the followers of her order ("suas filhas") "faz prometer pobreza" so that they may be "muito ricas" upon marrying, a clear reference to relationship between the vow of poverty and the union with Christ. Villancico IV poses the rhetorical question referring again to St. Clare, "De sus rentas, que dire, / Por Christo, no tiene nada, / Blanca seria su mano, / Pero nunca tuvo blanca", thereby pointing to both Clare's poverty and the resistance on the part of the community to any income that might distance them from their vows. Speaking again of St. Clare, Villancico IV indicates that "Tan pocas posses tenia, / Por la Trinidad Sagrada, / Que de un ayuno perpetuo / Siempre se hallò combidada". This allusion to the lack of food in the convent underscores both the importance of the vow of poverty among those in the convent and the shared experience of hunger, a recurring

${ }^{28}$ Bennett points out that "By the late $14^{\text {th }}$ century, the Poor Clares had acquiesced so significantly that when the granddaughter of English King Edward III joined in 1421, she brought with her embroidered bedsheets, tapestries and a supply of gold bars" (2016: n.p.). Likewise, the 1758 Mappa de Portugal notes the presence of both servants and slaves living in the Convent of Santa Clara.

UNED. REI, 8 (2020), pp. 53-77

ISSN 2340-9029 
theme in convent writing ${ }^{29}$ and one that contributed to the sense of community intramuros.

Another oft-repeated trope in convent drama is that of flower imagery. ${ }^{30}$ Villancico III in Sor Isabel's collection moves from a metaphorical description of Clare as the light of dawn to a comparison between the nuns and various flowers. It explains that in order to celebrate the aurora that brings with it "el divino Sol", or Christ, "El Cielo, y tierra se apresentan, / Con gala, y con resplendor". The stars and the flowers compete amongst themselves and "de todos los prados / Es todo un verde primor". Although the stars may outshine their terrestrial companions, the flowers are best positioned to greet the dawn: "El Clavel, y la Açucena, / Rosa, Jasmin, Girasol, / Como son hijas del Alva, / Le dan salva con primor". The aurora then comes to their balconies in response to their humility and worship. This description of the nuns as carnations, lilies, roses, jasmine, and sunflowers who praise the dawn positions the women as humble followers of St. Clare who, like the flowers of the field mentioned in the book of Matthew, ${ }^{31}$ have no need of fancy clothes nor,

${ }^{29}$ Sor Marcela de San Félix, for example, repeatedly employed the theme of hunger in her poetry and drama (including her loas and coloquios). This trope lent a humorous irony to her works, as Sor Marcela worked as the provisora (cellaress) in the discalced Trinitarian convent where she lived.

${ }^{30}$ Soror Maria do Céu, for example, penned a compendium of short texts, Metáforas das floras moralizadas em documentos muy proveitosos (1734), which explores the metaphorical significance of flowers such as rose, carnation, iris, and jasmine. Soror Maria also centered her comedia, Clavel, y Rosa (1736), on a metaphor that compared the Virgin Mary to a rose and St. Joseph to a carnation. For more on this play, see my articles "Upending Hegemonic Masculinity in Soror Maria do Céu's Clavel, y Rosa" (Halling, 2018) and "Soror Maria do Céu’s Virgin Mary and the Male Gaze" (Halling, 2019). Flower imagery also appears in many other villancicos of the time period. Even some convents, such as the Real Convento de Nossa Senhora da Esperança in Lisbon, were decorated with similar images from nature. The practice of planting "Mary gardens" ("small, enclosed, and full of symbolism-containing flowers and herbs named after Mary, created and cared for in her honor" [Krymow, 1999:8]) was widespread, as well, signaling the central role that nature played in Catholic devotion.

${ }^{31}$ Verses 28 and 29 of the sixth chapter of Matthew ask, "And why worry about clothing? Think of the flowers growing in the fields; they never have to work or spin; yet I assure by extension, worldly goods. This embracing of poverty certainly helped to form a sense of community in Sor Isabel's convent.

In contrast to the use of pacific flower imagery, one of the villancicos employs bellicose language to praise St. Clare. While this may seem strange for a convent text, convent writers repeatedly used metaphors related to war as a way to talk about and comprehend their own experience with spiritual trials. This was particularly true during the era of the Catholic Reformation for reformers such as Teresa de Âvila, for whom "the reform was a war in which God was the supreme commander or captain general, she was a general, her collaborators were lieutenants, and the nuns and friars were soldiers. The vocabulary of war permeates her writing" (Mujica, 2019: 69). Asunción Lavrin notes that at the moment a novice takes her vows, "love has already waged a battle to defeat worldly temptations ... The metaphor of triumph and conquest over self and evil conferred on nuns as women of valor and strength of soldiers sustained by the love of Christ" (2008: 91). It stands to reason, then, that the nuns of Sor Isabel's convent might also consider their saintly predecessor (and, by extension, each nun in the convent) as a soldier in the war against evil. Villancico V paints Clare as "La bellisima Belona". This metaphor compares the saint to Bellona, ancient Roman goddess of war equipped with deadly weapons and a chariot on which she rides into battle. The poem states that not only did the bellicose Clare attack the evil of the world ("ha metido a saco el mundo"), she also laid siege to the heavens ("puso sitio al Cielo") in order to open its doors to mankind, an allusion to her role as intercessor. The villancico also points to an important hagiographic story told about St. Clare in which she defended her cloister from an army of mercenaries by holding up the host: "en los aprietos le hallava / Com un thesoro en las manos, / Y pan para muchas almas". ${ }^{2}$

you that not even Solomon in all his royal robes was clothed like one of these" (The New Jerusalem Bible 1985: 1619).

${ }^{32}$ The Miracle of the Eucharist of Assisi occurred in 1240 or 1241, toward the end of St. Clare's life. At that time, Clare lived in the convent of San Damiano. The German emperor, Frederick II, hired an army of Saracen mercenaries to help him unite Italy against the wishes of Pope Gregory, whom Frederick considered "a heretic and a criminal" (Mueller, 2006: 86). When the army marched on the city of Assisi and began to scale the walls, 
This episode surely served as an example for the nuns, who often found themselves facing seemingly insurmountable physical and spiritual obstacles of their own in the convent. This reference to the founder of their order also must have strengthened their sense of community as the Poor Clares wrote collectively about the strength and bravery of St. Clare.

Not only do the sisters celebrate their patron saint, they also make explicit and implicit references to convent practices. In Villancico II, the reader finds a pun on the name "Clara" juxtaposed with the word "gema", thus referring both to St. Clare and to the eggs traditionally used in the creation of Portuguese convent pastries ${ }^{33}$ prepared for special occasions, such as saints days, Christmas, or the profession of a new nun. ${ }^{34}$ The pun "Que sendo no nome Clara, / He das virtudes a gema" suggests that although her name is similar to egg whites not used in the creation of convent treats, St. Clare, like the egg yolk, has great worth. The nuns usually used the "gema", or yolk (sweetened with sugar), rather than the "clara", or egg whites, to create these pastries, giving them a distinctly yellow hue. Although the 1755 earthquake levelled Sor Isabel's convent

the nuns, understandably, feared for their safety. Some accounts say that the soldiers even entered the cloister itself. The sisters appealed to Clare, the mother superior. She responded to the threat by having a monstrance containing the Eucharist placed on the walls of the convent. She then prayed and her pleading was answered by the voice of Christ, who promised to protect her and the city. The Moorish soldiers fled in the face of her immense courage. Because of this miracle, many depictions of St. Clare show her holding a monstrance.

${ }^{33}$ Examples of these sweets in their many varieties are found throughout Portugal. They are known as doces conventuais and include pastries such as tocinho do céu, queijada pastel de nata, meia-lua, and travesseiro. Convents produced these for their own consumption as well as for sale, as Isabel Drumond Braga explains: "as vendas de pratos salgados e sobretudo de doces eram uma constante" (2015: 37). She also explains that they were shared with the nuns' family members as well as travelers.

${ }^{34}$ Braga notes that "há uma relação directa entre a aquisição de determinados géneros alimentares e o calendário litúrgico" (2015: 34). Some records indicate which pastries were consumed for certain celebrations. Braga states that certain archival sources document the consumption of foods at different convents during various celebrations-for example, "Em Nossa Senhora da Encarnação, no Funchal, uma casa de clarissas, era habitual o arroz doce nos dias de Santa Clara e de São João. Nesse dia também se faziam bolos de cevada" (2015: 33) and records on the convent are scant and brief, Isabel Drumond Braga cites a document from the Conselho Geral do Santo Ofício that states that in 1693, the convent of Santa Clara produced ovos reais for the queen, D. Maria Sofia Isabel de Neuberg. ${ }^{35}$ This particular sweet generally requires twelve egg yolks and two egg whites, hence the reference to eggs in the villancicos that values the yolks more than the whites. The production of these sweets was a joint venture undertaken by the nuns and meant to benefit, through their sale, the convent as a whole. This reference to the making of convent sweets again points to the convent and the collective practices that make it a communal space.

Although modern scholars often privilege single-authored texts as proof of literary genius, the collaborative villancicos produced by the nuns of the Convent of Santa Clara reveal an impulse to collaborate. The dramatic poems point both outward to the patron saint of the Poor Clares and inward to the convent space and its practices. Unlike villancicos attributed to a single author, such as those of Soror Violante do Céu, these reveal a collaboration colored by a profound sense of community. Unlike other anonymously published villancicos, this collection calls attention to its collaborative nature. The social and religious relations among the women in the Santa Clara convent paved the way for a communally written text that self-consciously doubles back on itself. The intramuros space allowed the nuns to foment a written culture and thereby nurture a collective feminine authorial voice. Unlike the public sphere, the private and enclosed convent space provided fertile ground for collaborative literary creation. In these villancicos, we clearly hear the voices of the women of the Poor Clares community as they join together in praise, humility, obedience, and sacrifice.

Received: 01/06/2020

Accepted: 24/08/2020

${ }^{35}$ According to Braga, the "ovos reais de Santa Clara" cost 4,000 réis and were sent to the Palácio dos Estaus (located in Rossio Square in Lisbon) for the queen to taste (2015: 39). 


\section{Works cited}

Bagnall Yardley, Anne (1990), "The Marriage of Heaven and Earth: A Late Medieval Source of the Consecratio virginum", in Studies in Medieval Music Festschrift for Ernest H. Sanders, New York: Columbia University, pp. 305-324.

Baranda, Nieves (2011), "Plumas en el claustro. Formas de escritura conventual femenina en el Siglo de Oro", in Antonio Azaustre Galiana y Santiago Fernández Mosquera (coords.), Compostela Aurea. Actas del VIII Congreso de la AISO. (Santiago de Compostela 7-11 de julio de 2008), Santiago de Compostela: Universidade, t. III, pp. 569-576.

Bellini, Lígia and Moreno Laborda Pacheco (2009), "Experiência e ideais de vida religiosa em mosteiros portugueses clarianos, nos séculos XVII e XVIII", Revista de História, 160, pp. 147-167

Bennett, Veronica, et al (2016), Looking Good: A Visual Guide to the Nun's Habit, London: GraphicDesign\&.

Bombi, Andrea (2019), “ ¿Hacia una historia del villancico? Problemas historiográficos de un género musical”, in Esther Borrego Gutiérrez and Javier Marín López (eds.), El villancico en la encrucijada: Nuevas perspectivas en torno a un género literario-musical (Siglos XV-XIX), Kassel: Edition Reichenberger, pp. 3-22.

Borrego Gutiérrez, Esther (2012), "Los autores de las letras de los villancicos de la capilla real de Madrid (Siglo XVII): ¿anonimia como costumbre u ocultamiento de identidades?", Revista de Musicología, 35.2, pp. 97-129.

Braga, Isabel Drumond (2015), Sabores e Segredos: Receituários Conventuais Portuguesas da Época Moderna, Coimbra: Coimbra UP.

Castro, João Bautista de (1758), Mappa de Portugal: Quinta Parte, Lisboa: Francisco Luiz Ameno.

Certeau, Michel de (1984), The Practice of Everyday Life, trans. Steven Rendall, Berkeley: U of California P.

Codet, Cécile (2012), "Edición de la Suma y breve compilación de cómo han de bivir y conversar las religiosas de Sant Bernardo que biven en los monasterios de la cibdad de Ávila de Hernando de Talavera (Biblioteca del Escorial, ms. a.IV-29)", Memorabilia, 14, pp. 1-57.

Constituiçoens geraes pera todas as freiras, e religiosas sogeitas à obediencia da Ordem de N. P. S. Francisco, nesta Familia Cismontana (1693), Lisboa: Miguel Deslandes <http://purl.pt/24049>

Emmerich, Karen (2017), Literary Translation and the Making of Originals, New York: Bloomsbury.

Erne, Lukas (2008), Shakespeare's Modern Collaborators, London: Continuum.

García de la Concha, Víctor, and Ana María Álvarez Pellitero, eds. (1982), Libro de Romances y Coplas del Carmelo de Valladolid, Salamanca: Consejo General de Castilla y León, Servicio de Publicaciones.

Gómez, Maricarmen (2006), "On the Origins of the Christmas 'Villancicos"', in Commemoration, Ritual and Performance: Essays in Medieval and Early Modern Music, Ottowa: The Institute of Medieval Music, pp. 53-69.

Halling, Anna-Lisa (2017), "Space, Performance, and Subversion in Sóror Violante do Céu’s Villancicos”, Comedia Performance, 14:1, pp. 71-105.

--- (2018), "Upending Hegemonic Masculinity in Soror Maria do Céu’s Clavel, y Rosa", Journal of Lusophone Studies, 3.1, pp. 50-69.

--- (2019), "Soror Maria do Céu's Virgin Mary and the Male Gaze", Via Spiritus, 26, pp. 165-83.

Hirschfeld, Heather (2001), "Early Modern Collaboration and Theories of Authorship", PMLA, 116:3, pp. 609-22.

Howe, Elizabeth Teresa (2015), Autobiographical Writing by Early Modern Women, Oxfordshire: Routledge.

Krymow, Vincenzina (1999), Mary's Flowers: Gardens, Legends \& Meditations, Cincinnati: St. Anthony Messenger Press. 
Laird, Paul R. (1997), Towards a History of the Spanish Villancico, Sterling Heights: Harmonie Park P.

Lavrin, Asunción (2008), Brides of Christ: Conventual Life in Colonial Mexico, Stanford: Stanford UP.

Lefebvre, Henri (1984), The Production of Space, trans. Donald Nicholson-Smith, Malden, MA: Blackwell Publishing.

Lehfeldt, Elizabeth A. (2005), Religious Women in Golden Age Spain: The Permeable Cloister, Oxfordshire: Routledge.

Limbert, Claudia A. and John H. O’Neill (1993), “Composite Authorship: Katherine Philips and an Antimarital Satire", Papers of the Bibliographical Society of America, 87:4, pp. 487- 502.

Longfellow, Erica (2016), "Lady Anne Southwell's Indictment of Adam", Early Modern Women's Manuscript Writing: Selected Papers from the Trinity/Trent Colloquium, n.p.: Routledge, pp. 111-133.

Maria do Céu, Soror (1735), "Metáforas das flores moralizadas em documentos muy proveitosos", in Obras varias e admiraveis, Lisboa: Costa, pp. 1-53.

--- (1736), "Clavel, y Rosa, breve comedia aludida a los desposorios de María y José", in Enganos do bosque, desenganos do rio, Lisboa: Costa, pp. 249-309.

Morris, Michael (2006), Francis \& Clare of Assisi: Selected Writings, San Francisco: Harper Collins.

Mueller, Joan (2006), The privilege of Poverty: Clare of Assisi, Agnes of Prague, and the Struggle for a Franciscan Rule for Women, University Park: Pennsylvania State UP.

Mujica, Bárbara (2009), Teresa de Avila: Lettered Woman, Nashville: Vanderbilt UP.

The New Jerusalem Bible (1985), Garden City: Doubleday.

Padilla Manrique y Acuña, Luisa María (1642), Excelencias de la castidad, Zaragoza: Pedro Lanaja, y Lamarca. tin P.

Sanz, Gabriel (1681), Ceremonial del convento, y religiosas trinitarias descalzas, redempcion de cautivos, de San Ildefonso desta corte, Madrid: Francisco Sanz.

Soja, Edward W. (1996), Thirdspace, Cambridge, MA: Blackwell.

Spain, Daphne (1992), Gendered Space, Chapel Hill: U of North Carolina P.

--- (1993), “Gendered Spaces and Women's Status", Sociological Theory, 11.2, pp. 37-151.

Spivey Ellington, Donna (2001), From Sacred Body to Angelic Soul, Washington, D.C.: Catholic U of America P.

Torrente, Álvaro (2016), "El villancico religioso", in Álvaro Torrente (ed.), Historia de la música en España e Hispanoamérica. Vol. 3. La música en el Siglo XVII, Madrid: Fondo de Cultura Económica de España, pp. 433-530.

Villancicos que se cantaram as religiosas de S. Clara, em o seu dia, no Real Convento de Lisboa: Sendo Vigaira do Coro a Madre Sór Isabel do Nacimento (1671), Lisboa: Antonio Craesbeeck de Mello.

Violante do Céu, Soror (1733), Parnaso Lusitano, Lisboa: Officina de M. Rodrigues.

York, Lorraine Mary (2002), Rethinking Women's Collaborative Writing: Power, Difference, Property, Toronto: U of Toronto P, Scholarly Publishing Division. 